\title{
AN ANALYSIS OF STUDENTS' DIFFICULTIES IN COMPREHENDING NARRATIVE TEXT
}

\author{
By: \\ Desi Sapitri, Fitri Novia, Rachmanita \\ English Language Education Study Program at FKIP Islamic University of Ogan \\ Komering Ilir Kayuagung, South Sumatera \\ ecifahri@gmail.com,novia_f@uniski.ac.id.,ayuksulung2407@gmail.com
}

\begin{abstract}
The objective of this study was to find out students' difficulties faced by the Eight Grade Students at SMP N3 Tanjung Raja in Comprehending English reading text. The method was used descriptive qualitative research. The participants of this study was all of the eighth grade students of SMP Negeri 3 Tanjung Raja. The technique for collecting the data was multiple choice. Based on the result, it was found that the percentage of difficulty in indicator not clearly stated information was $55.90 \%$, the percentage of difficulty in indicator reference of the text was $59.54 \%$, the percentage of difficulty in indicator find moral value of the text was $64.23 \%$, the percentage of difficulty in indicator find the deducing meaning was $55.27 \%$, the percentage of difficulty in indicator find the specific information was $56.35 \%$, the percentage of difficulty in indicator find the detailed information was $67.05 \%$, and the percentage of difficulty in indicator find the main idea was $54.81 \%$.
\end{abstract}

Keywords: reading comprehension, students' difficulties, narrative text

\section{INTRODUCTION}

Reading is one of the four

basic skills to be taught for the students. According to Halik (2016, p.149), reading is the activity between the reader and the writer's idea, where the writer sends his idea in the written symbols and then the reader catching the idea in it. In addition, reading is one activity that cannot be released in our life to search for information or knowledge from textbooks, articles, or magazines written in English (Asmawati, 2015, p.69). Moreover, Septiana (2019, p.105) states that reading is an activity to get much information and knowledge, for example, read books, newspapers, and magazines. 
Moreover, reading skill is very important for students. According to Mardianti and Ohoiwutun (2014, p. 1), the teaching of reading is very important because it helps the students to have more skills in comprehending and interpreting the content of an English text. In addition, reading is one of the most important means by which it required knowledge or information from the world around us (Yang, 2016, p.586). It can be concluded that reading is an important activity of the learners in life and it is an effort to acquire language, communicate with the text, and can improve someone's writing, speaking, listening, grammar, and any other subjects through comprehension.

In addition, reading can not be separated from comprehension. Reading comprehension is the process of constructing meaning by connecting what has been read to what the reader already knows and thinks about all of this information until it is understood (Kirmizi,2010, p.4753). Moreover, Wooley (2011, p.15) states that comprehension involves the interaction of a wide range of cognitive skills and processes that there are many occasions where difficulties arise that may lead to comprehension failure. In addition, reading comprehension is the essence of the reading process (Varita, 2017, p.236). It can be concluded reading comprehension is the understanding of the information between word and sentences used to obtain the information from a reading passage through reading comprehension skills.

Nevertheless, reading is not easy for students. According to 
Alderson (2010, p. 108), many EFL students are still struggling to overcome the reading problem due to the long passage and limitation of the vocabulary. In addition, Moghadam, Zainal, and Ghaderpour (2012) state that when a reader does not know many words in a text, such a condition would hinder the effectiveness and efficiency of the text processing, which leads to difficulties in the reader comprehending the text. Moreover, Davoudi and Yousefi (2015, p.60) have listed several EFL learners reading difficulties and problems such as deficits in vocabulary knowledge and background knowledge, problems with grammatical knowledge, and also poor reading strategies which is very important to reduce the difficulties. Furthermore, Chen and Chen (2015, p.157) state that most learners have reading problems because they lack the specific strategies necessary for efficient reading. Besides, Dwiarti (2005, p.89) mention that there are four problems that the students facing in finding main idea of the text, there are: 1) lack of interest toward reading, 2) lack of background knowledge, 3) lack of vocabulary, and 4) unware on the parts of the paragraph. When foreign language reading is a laborious, unpleasant, and unsuccessful process, readers will often be unwilling to read in the target language. In short, most of the students are difficult to read long passages because they feel bored, and they do not interesting when they are reading that makes them poor readers, and they are difficult to 
understand the idea of the passage because they are lack vocabulary.

A narrative text tells about past events and has a meaningful story. According to Rohmana, Syahri, and Sulaiman (2019, p.104), narrative text is a story that is created in a constructive format that describes a sequence of fictional or non-fictional events. Furthermore, narrative text can be an imaginary story or based on a real incident (Latifa and Manan, 2018, p.249). It is called imaginary because the story is not necessarily telling the truth but it could be just imagination or fictional story made by someone or a group of people who have not proven the truth. Moreover, narrative text is a story with complications or problematic events and it tries to find the resolutions to solve the problems.
Nevertheless, there are some problems in reading narrative text. According to Lisandi and Adijaya (2019, p.54), reading narrative text is considered as a boring activity for them because while reading the students found many problems such as they are required to comprehend a whole reading text, find the main idea, conclude the content of the text and at the end, they have to answer the question related to the story correctly. In addition, Herlina (2012, p.148) says that a narrative text is a difficult text for students to learn as it is long and having the sequence.

Based on the interview toward some students of SMP N3 Tanjung Raja, the researcher found that the students agreed that reading comprehension is difficult to understand. That is proved by the students' achievement in 
comprehending reading narrative text. The students told that it happened because of some factors such as the teachers' strategy in teaching reading was not interesting and make them bored, the students were not familiar with the topic, then the students were still the lack of vocabulary and grammatical punctuation.

This study is intended to answer the research questions about what are the students' difficulties in comprehending narrative text viewed from not clearly stated information reference, moral value, deducing meaning, specific information, detailed information, and main idea indicators. It is purposed to find out the students difficulties in comprehending narrative texts at SMPN 3 Tanjung Raja and identify the problems which may cause the students' difficulties in comprehending narrative texts at SMPN 3Tanjung Raja. The subject of this study is the students of SMPN 3 Tanjung Raja on Eighth Grade in academic year 2019/2020 and focuses in the difficulties faced by the students of SMPN 3 Tanjung Raja on Eighth Grade in comprehending narrative text.

\section{METHODOLOGY}

The design of this research was a descriptive qualitative research to see the students' ability and difficulty in answering reading test. The population of this research was all the second year students of SMPN 3 Tanjung raja. The number of sample were 55 students. The sample of this research was taken by purposive sampling method. The researcher used purposive sampling 
method because The characteristics of the sample were having the same total number in terms of male and female students. Multiple choice about reading narrative text was used to collect the data. Percentage was used to analyze the data.

\section{RESULTAND DISCUSSION}

Based on the result clearly stated information indicators, the percentage of students with difficulty was $55.90 \%$. Based on the analysis of the reference indicators, the percentage of students with difficulty was $56.01 \%$. Based on analyzing the moral value indicators, the percentage of students with difficulty was $56.60 \%$. Based on the result of the specific information indicators, the percentage of students with difficulty was $56.35 \%$. Based on identifying the detailed information indicators, the percentage of students with difficulty was $67.05 \%$.

In summary,it showed that the higher percentage of difficulty was $67.05 \%$ in find the detailed information indicator, percentage of difficulty was $62.01 \%$ in reference indicator, percentage of difficulty was $56.60 \%$ in moral value, percentage of difficulty was $56.35 \%$ in specific information, percentage of difficulty was $55.90 \%$ in not clearly stated information, percentage of difficulty was $55.62 \%$ in deducing meaning, and percentage of difficulty was $54.81 \%$ in main idea indicators. It was happened because the students had difficulty in understanding the long sentence and were lack of vocabulary that made the students in SMPN3 Tanjung Raja did not understand the meaning of the text or sentences. As a result,the students 
could not answer the questionrelated to the text correctly.

This result was in lined with statement of According to Alderson (2010, p. 108) who stated that many EFL students are still struggling to overcome the reading problem due to long passage and limitation of the vocabulary. In addition, Davoudi and Yousefi (2015, p. 60) have listed several EFL learners reading difficulties and problems such as deficits in vocabulary knowledge, problems with grammatical knowledge, and also poor reading strategies which is very important to reduce the difficulties. Moreover, Dwiarti (2005, p. 89) mention that there are four problems that the students facing in finding main idea of the text, the are : 1) lack of interest toward reading, 2) lack of backgroud knowledge, 3) lack of vocabulary, and 4) unware on the parts of the paragraph.

\section{CONCLUSION}

Based on the result of the test, it showed that the percentage of students with difficulty. The percentage of students with difficulty was $55.90 \%$ in indicator not clearly stated information, the percentage of students with difficulty was $59.54 \%$ in reference indicator question, the percentage of students with difficulty was $64.23 \%$ in moral value indicator, the percentage of students with difficulty was $55.27 \%$ in deducing meaning indicator, the percentage of students with difficulty was $56.35 \%$ in the specific information indicator of the question, the percentage of students with difficulty was $67.05 \%$ in the detailed information question indicator, the percentage of students 
with difficulty was $54.81 \%$ in main idea indicator. Most of the students had difficulty in reading because they had limited of vocabulary and rarely read that made them confused when reads answer the text and answer the questions.

\section{REFERENCES}

Alderson, J. C. (2010). Assessing reading.Cambridge:

Cambridge University Press.

Asmawati, A. (2015). The effectiveness of skimming scanning strategyin improving students' reading comprehension atthe second grade of SMK Darussalam Makassar. Unpublished thesis Retrieved

from://www.google.com/url?sa $=\mathrm{t} \&$ source $=$ web $\& \mathrm{rct}=\mathrm{j} \&$ url $=\mathrm{htt}$ $\mathrm{p}$ ://journal.uin alauddin.ac.id/index.php/Etern al/article/download/2409/2323 \&ved=2ahKEwiWh5W2gYnm AhWFYysKHfHXBoMQFjA WegQIAxAB\&usg=AvVaw3Q Bt3MyU7HGnN73QdwxTRL \& cshid $=1574810797842$

Chen, S.C., \& Chen, K.T. (2015). The use of EFL reading strategies among high school students in Taiwan. The reading matrix, 15(2),156-166. Retrieved fromhttps://www.google.com/u $\mathrm{rl}$ ? $\mathrm{sa}=\mathrm{t} \&$ source $=$ web\&rct $=\mathrm{j} \&$ ur $\mathrm{l}=\mathrm{http}: / / \mathrm{www}$.radingmatrix.co m/files/13m0137054.pdf\&ved $=2$ ahUKEwioucuuwPbmAVwI LcAHVJrBvgQFjAegQIARA \&usg=AOvVaw218XFONAhe Xft3 O hBt95.

Davoudi, M., \& Yousefi, D. (2015). Comprehension breakdown: a review of research on EFL learners ${ }^{\text {ee }}$ reading difficulty and problems. International Journal of Language and Applied Linguistics, 1(2), 5872.Retrieved from https://.google.com/url?sa=t\&s ource $=$ web\&rct $=\mathrm{j} \&$ url $=\mathrm{http} ; / \mathrm{k}$ hatesefid.c/journal/wpcontent/u ploads/2015/07/58721.pdf\&ve $\mathrm{d}=2$ ahUKEwja272DwbmAhUo 1LcAHZboAgQIAhAB\&usAO vVaw1ISg6vRxcWTRnmJAcQ hK8.

Dwiarti, E. (2005). An analysis of students' problems in finding the main idea of the text at second year of SMU Kosgoro Sekampung. Unpublished Thesis. Retrieved from https://www.google.com/url?sa $=\mathrm{t} \&$ source $=$ web\&rct $=\mathrm{j} \&$ url $=\mathrm{htt}$ ps://textid.123dok.com.

Halik, N. (2016). Contextual teaching and learning method to in teachhing readingat third year students of MTSN Balang-Balang Gowa Regency. Retrived fromhttps://www.google.com/u 
$\mathrm{rl}$ ? $\mathrm{sa}=\mathrm{t} \&$ source $=$ web \&rct $=\mathrm{j} \&$ ur l=http:/journal.uinalauddin.ac.i $\mathrm{d} /$ index.php/Eternal/article/dow nload $/ 2390 / 2997$ ved=2ahUKE wivhNjO9dXmAhXJbSsKHbU 8CAQFjAPegQIChAB\&us=A OvVaw310Eu5AlJeq85K4csI6 GEX\&cshid $=1577455293803$.

Herlina. (2012). Developing reading narrative text materials for eighth graders of junior high school implemented with character building. English Education Journal, 2(2),148154. Retrieved fromhttps://www.google.com/url $? \mathrm{sa}=\mathrm{t} \&$ source $=$ web\&rct $=\mathrm{j} \& u r l=$ https://journaunnes.ac.id/sju/inde x.php/eej/article/view/675\&ved= 2ahUKEwjVsuvElsqAhXGfX0 KHTE7DR8QFjAAegQIBhAB \&usg=AOvVaw2sMBfRBeg8

Kirmizi, F.S. (2010). Relationship between reading comprehension strategy use and daily free reading time. Procedia-Social and Behavioural Sciences.2, 4752-4756.

Latifa, N., \& Manan, A. (2018). Teaching narrative text by using preview, question, read, state, and test (PQRST) technique. English Education Joural (EEJ), 9(2),243-260. Retrieved fromhttps://www.google.com/url $? \mathrm{sa}=\mathrm{t} \&$ source $=$ web\& $\mathrm{rct}=\mathrm{j} \&$ url $=$ http://www.jnal.unsyiah.ac.id/E EJ/article/download/11547/9262 \&ved=2ahUKEwijlZslc_qAhXE AnIKHdDwAlIQFjAAegQIBR AB\&usg=AOvVaw32tp2KarXH KVDCo0M2KSq
Lisandi, N., \& Adijaya, N. (2019). The effectiveness of using collaborative strategic reading (CSR) on students' reading comprehension of narrative text. English Language in Focus. Retrieved fromhttps://www.google.com/url $? \mathrm{sa}=\mathrm{t} \&$ source $=$ web $\& \mathrm{rct}=\mathrm{j} \&$ url $=$ https://jurnalj.ac.id/index.php/E LIF/article/view/4873\&ved=2ah UKEwiczq7Rk8_QaX0KHclsCe EQFjACegQIBhAC\&usg=AOv Vaw2dLRhNq_t_KRXgSmsYG A6

Mardianti, V., Jos. E.,\& Ohoiwutun, W. (2014). Improving students' reading comprehension through schema activation strategy. E-Journal of English Language Teaching Society ELTS), 2 (1), 1-16. Retrieved from http://jurnal.untad.ac.id/index.ph p/ELTS/article/view/3020.

Moghadam, S. H., Zainal, Z. \& Ghaderpour, M. (2012). A review on the important role of vocabulary knowledge in reading comprehension performance. Procedia Social and Behavioural Sciences, 66, 555 563. Retrieved fromhttps://www.google.com/url $? \mathrm{sa}=\mathrm{t} \&$ source $=$ web\& $\mathrm{rct}=\mathrm{j} \&$ url $=$ https://cyberlninka.org/article/n/ 1258072.pdf\&ved=2ahUKEwiT rdmZy bmAhWFc30HYL2Bdg QFjACegQIBBAB\&usg $=\mathrm{AOvV}$ aw2CnqXqJ2MSwemQwh94W W.

Rohmana, H.S., Syahri, I., \& Sulaiman, M. (2019). Teaching 
reading narrative text through inking your thinking strategy. ELT-Lectura, $\quad 6(2), 102-$ 113.Retrieved from https://www.google.com/url?sa= t\&source $=$ web\&rct $=\mathrm{j} \& u r l=h t t p s:$ //journaunilak.ac.id/index.php/E LTLectura/article/view/2960\&ve $\mathrm{d}=2$ ahUKEwjepOYk8_qAhUYd CsKHW61DR4QFjAAegQIBhA C\&usg=AOvVaw30e07TdnoQ1 FDyNbD85qI

Septiana, R. (2019). Teaching reading narrative texts through chunking strategy.

English Empower, 3 (2), 105113. Retrieved from http://www.ejournal.unitaspale mbang.ac.is/index.php/eejll/arti clview/79/70.

Varita, D. (2017). Improving reading comprehension through Literature circles. English

Education Journal (EEJ), 8(2),234-244. Retrieved fromhttps://www.google.com/url ?sa $=\mathrm{t} \&$ source $=$ web\& $\mathrm{rct}=\mathrm{j} \&$ url $=$ http://urnal.uyiah.ac.id/EEJ/artic le/download $/ 7231 / 5943 \&$ ved $=2 a$ hUKEwiu0Xbgonm hXB63MB HbcDAgoQFjADegQICRAB\&u sg=AOvVaw2inleDjM1_6y_j00 yLVO\&cshid $=1574810753156$

Yang, X. (2016). Study on factors affecting learning strategies in reading comprehension.

Journal of Language Teaching and Research. 7(3). 586590.

DOI:

http://dx.doi.org/10.1750/jltr.070 3.21 